\title{
Investigating Fiscal Dominance in Nigeria
}

\author{
Kazeem Abimbola Sanusi ${ }^{1} \&$ Anthony Enisan Akinlo ${ }^{1}$ \\ ${ }^{1}$ Department of Economics, Obafemi Awolowo University, Ile-Ife, Nigeria \\ Correspondence: Kazeem Abimbola Sanusi, Department of Economics, Obafemi Awolowo University, Ile-Ife, \\ Nigeria. E-mail: sanusikazeemabimbola@yahoo.com; aakinlo@oauife.edu.ng
}

$\begin{array}{lc}\text { Received: October 18, } 2015 & \text { Accepted: December 7, } 2015 \text { Online Published: January 26, } 2016 \\ \text { doi:10.5539/jsd.v9n1p125 } & \text { URL: http://dx.doi.org/10.5539/jsd.v9n1p125 }\end{array}$

\begin{abstract}
This paper investigates the presence or otherwise of fiscal dominance in Nigeria during the period of 1986-2013 using structural VAR analysis. Annual secondary data were used for the study. Data on fiscal deficits and monetary base were obtained from the publication of Central Bank of Nigeria Statistical Bulletin. The results show that shock to fiscal deficits of government does not stimulate response from the growth of monetary base. In addition, the results show that there exists no causality running from fiscal deficits to growth of monetary base in Nigeria. The study concludes that there is no evidence of fiscal dominance in Nigeria during the study period.
\end{abstract}

Keywords:fiscal dominance, SVAR, Nigeria

\section{Introduction}

Many theoretical and empirical studies have identified several channels through which fiscal and monetary policies are linked together,( Aiyagari,and Gertler, 1985; Favero, 2002; Nawaz et al.2012; Xiong, 2012 Sargent and Wallace, 1981). For example, macroeconomic theory argues that fiscal deficit causes inflation because governments that face persistent fiscal deficits find money creation as solution to offset the deficits, leading to inflation as a monetary phenomenon. This hinders the effectiveness of monetary policy in maintaining price stability objective.

Fiscal dominance is one of the ways in which fiscal and monetary policies are linked to each other. It describes the situation in which the monetary authority accommodates fully, all government debts. In other words, the monetary authority accommodates the fiscal authority whenever a budget deficit is financed with debt. This accommodation is in form of an increase in current or future seigniorage revenues to finance the principal and interest payments on the newly issued debt. The implication of this is that fiscal authority is insensitive or irresponsive to monetary policy in that neither taxes nor expenditure react (today or in the future), to changes in stock of outstanding government debt and therefore fiscal deficits have to be financed by creation of base money. This situation has generally been regarded as fiscal dominance, (Leeper, 1991 and Sargent and Wallace, 1981). This implies that fiscal dominance is counter-productive to the overriding objective of monetary policy which is maintenance of price stability. Undoubtedly, the presence or otherwise of fiscal dominance has generated heat debate in the literature. For instance, many studies have established the presence of fiscal dominance Some of such studies are Sargent and Wallace (1981), Mellits (1997), Favero and Spinelli (1999), Sabate, Gadea and Escario (2004) and Makochekanwa (2011). However, there exists ample of other empirical studies that could not substantiate the evidence of fiscal dominance ( Barro 1987; Bohn 1998; Canzoneri, Cumby and Diba 2001; Creel and Le Bihan 2006). This present study revisits the issue surrounding the presence or otherwise of fiscal dominance. To the best of our knowledge, no study has been carried out to investigate the presence or otherwise of fiscal dominance in Nigeria. Hence, this study.

The remaining discussion is structured as follows: Section 2 gives some insights about macroeconomic environment in Nigeria that motivated this study. Review of empirical literature is contained in Section 3 and Section 4 contains the model and econometric procedures. Section 5 presents results estimation, discussions and policy implications of the results. The last section gives the concluding remarks.

\section{Overview of Macroeconomic Environments in Nigeria}

A proper understanding of a country's fiscal system requires adequate discussion of the movement of government revenue and government expenditure over time (Ayodele and Falokun, 2003). Since the oil boom of the 1970s, the Nigerian economy has remained largely undiversified.The overwhelming share of exports and 
government revenue depend on oil. Government expenditure in Nigeria has been volatile and highly pro-cyclical. This is because government spending has been rising in tandem with persistent rise in oil prices and oil revenue, until recent times (late 2014).

Successive governments in Nigeria have gone on a spending and borrowing spree during oil booms in 1970, early 1980s and the 1990s as well as early 2000s until 2014 when the oil price crashed in the world market. Oil price volatility and revenue volatility were much worsened by the country's loose fiscal policy. As oil prices increased, so did the fiscal revenues that government could collect from oil, and government spending (Okonjo-Iweala, 2011).

Consequent upon the volatility of government expenditure, the fiscal operations of the federal government of Nigeria since 1970 have been largely in deficits. In the early 1970s, fiscal operations recorded surpluses. The overall budget surplus as a percentage of GDP ranged from only 1.5 percent in 1973 to 9.8 percent in 1974 . Between 1975 and 1978, fiscal operations resulted in deficits. The surpluses recorded in the early 1970s ceased as a result of falling oil prices in the international market, leading to declines in government revenue. Consequent upon the inability of the government to respond immediately to the falling revenue by cutting down its expenditure, overall deficit-GDP ratio, which was 2.0 percent in 1975, rose to as high as 7.8 percent in 1978 .

In the 1980s, government expenditures, both capital and recurrent, were further fuelled by the execution of such programmes as States creation, wage increase and construction of new Universities. These new public institutions needed take-off grants and basic infrastructures to start off. This resulted in an overall deficit of up to 5.7 percent of GDP in 1986, and in 1993. With declining revenue from the oil sector, the shortfalls between falling revenues and rising expenditures were met through foreign borrowing and the Central Bank. There were pressures on government to cut expenditure because of the ugly consequences of both sources of financing deficits. Most capital projects involving key social infrastructures like public roads, healthcare facilities, among others, could not be funded because government could hardly afford to fund its recurrent expenditures.

The inception of democratic administration in 1999 ushered in another era of bogus spending, normally associated with civilian governments. The deficit-GDP ratio hit 5.9 percent in 1999 before falling to 1.5 and 1.1 percent in 2000 and 2005, respectively. The oil sector faced production challenges in 2014 achieving an average daily production of $2.2 \mathrm{mbpd}$ compared to the budget of $2.38 \mathrm{mbpd}$.Overall, the sector grew in the first quarter of 2014 by $5.14 \%$; second and third quarters declined by $6.6 \%$ and $3.6 \%$, respectively.

A cursory look at 2015 budget showed that the estimated aggregate expenditure is N4.358 trillion. This is about $8 \%$ less than the amount for 2014. This expenditure figure consists of N412 billion for statutory transfers (for national assembly, judiciary etc.), N943 billion for debt service, N2, 616 billion for recurrent (non-debt) expenditure and N634 billion for capital expenditure (including SURE-P). The recurrent expenditure increased by about $6.5 \%$ while capital expenditure declined by $43 \%$. Sadly enough, debt service is expected to increase. The proposed increase in debt service expenditure is $32.4 \%$ compared to $20.3 \%$ in the 2014 budget estimate.

The cost of servicing debt has been on the increase in the past three years and is expected to gulp about $26 \%$ of 2015 's aggregate revenue of the federal government. Inefficient trade and exchange rate policies, unfavourable exchange rate movements, unfavourable interest rate movements, poor lending and inefficient loan utilisation, poor debt management practices, and accumulation of arrears and penalties have been said to be the cause of persistent high debt profile in Nigeria (Debt Management Office, 2015). Given the significant decline in capital expenditure, it appears that funds are being borrowed to finance recurrent expenditure rather than developmental projects. It must however be clearly stated that as a percentage of GDP, the deficit to GDP ratio is $0.79 \%$ of GDP down from $1.24 \%$ in the 2014 budget and below the 3\% of GDP specified in the Fiscal Responsibility Act of 2007.

It is evident from the above that the profile of Nigeria's deficits has reached a level of deep concern to many, most especially policy makers and researchers. The Nigerian government has been running budget deficits since the civil war years. As a matter of facts, for about 39 out of 50 years computed from 1965 to 2015, Nigeria's overall fiscal position had been said to be in deficits. In other words, over $78 \%$ of our fiscal disposition is tilted in favour of deficit. The deficits as a percentage of GDP have continued to be on the increase and the immediate results are harmful to the economy such as increased debt among many others. For instance, the size of external debt as at the end of 2013 stood at USD45.7 billion, while the total external debt as at 2015 was put at USD60billion and there is no indication that it might decline in the next few years, especially with the current challenges in oil-revenue flows. The extent to which successive fiscal deficit has taken its toll on monetary growth in Nigeria is the concern of this study. 


\section{Empirical Evidence}

A growing body of literature has investigated fiscal dominance in various countries with mixed evidence. Joines (1986) reviewed the evidence on fiscal dominance in United States and found almost an equal number of authors finding and failing to find a positive relation between government deficits and money growth or the growth of the monetary base. Meanwhile, his conclusion on controversial evidence on fiscal dominance has not significantly changed over the years as evident in the recent studies. In other words, evidence on fiscal dominance is still largely debatable and controversial. Fry (1998) examined the fiscal dominance and Central Bank independence in some developing countries. He found out that Central Bank independence in those countries was determined by both the size of the government's deficit and the methods by which it is financed. This is consistent with earlier studies by Aiyagari and Gertler (1985), De Resende (2007), Favero and Spinelli (1999). Public finance has been said to exert strong influence on monetary policy. In other word, government spending is a critical factor in explaining the expected growth of the money stock, (Frattiani and Spinell, 2001; Gallo and Otranto, 1998; and Sabaté et al, (2004). Unsustainable current and non-development expenditures of government have been major causes of continuous fiscal imbalances, most especially in developing countries and thus create the problem of fiscal dominance. Evidence from Zimbabwe shows that current and non-development expenditures of government have motivated persistent fiscal deficit that is covered by seigniorage thus, leading to inflation (Makochekanwa, 2011 and Keen and Wang, 2013).

\section{Model and Econometric Procedures}

The method commonly adopted in the literature for assessing the fiscal dominance hypothesis is to verify the existence of causal link between budget deficit and development in monetary base. This follows the formal test of fiscal dominance as proposed by Fratianni and Spinnelli (2001) and Xiong (2012).

Fratianni and Spinnelli (2001) argued that there must be a positive relationship between budget deficit and growth of monetary base and not vice versa. To this end, this study follows the procedures of Fratianni and Spinnelli (2001), and therefore estimates a bivariate VAR model which includes budget deficit $y_{t}$ and growth of monetary base, $x_{t}$ in achieving objective of the study.

The VAR model to be estimated can be expressed as follows:

$$
\left[\begin{array}{cc}
1 & b_{12} \\
b_{21} & 1
\end{array}\right]\left[\begin{array}{l}
Y_{t} \\
X_{t}
\end{array}\right]=\left[\begin{array}{l}
b_{10} \\
b_{20}
\end{array}\right]+\left[\begin{array}{ll}
\gamma_{11} & \gamma_{12} \\
\gamma_{21} & \gamma_{22}
\end{array}\right]\left[\begin{array}{l}
Y_{t-1} \\
X_{t-1}
\end{array}\right]+\left[\begin{array}{l}
\epsilon_{y t} \\
\epsilon_{x t}
\end{array}\right]
$$

Where $b$ and $\gamma$ are coefficients, $\in$ is a white noise shock. The structure of the system allows the $Y_{t}$ and $X_{t}$ i.e fiscal deficits and monetary growth to have contemporaneous effects on each other.

$$
\text { Let } \quad \mathbf{B}=\left[\begin{array}{cc}
1 & b_{12} \\
b_{21} & 1
\end{array}\right]
$$

The structural VAR 4.21 can be transformed into a standard VAR model by pre-multiplyingB ${ }^{-1}$ on both sides of

Or simply

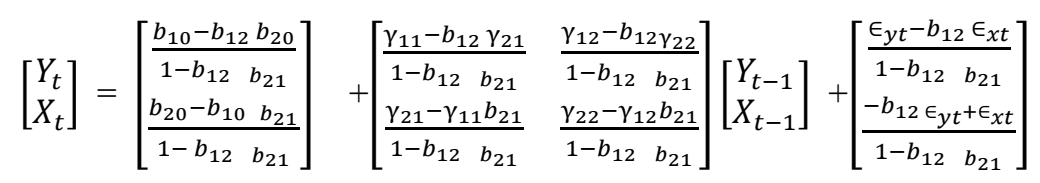

$$
\left[\begin{array}{l}
Y_{t} \\
X_{t}
\end{array}\right]=\left[\begin{array}{l}
a_{10} \\
a_{20}
\end{array}\right]+\left[\begin{array}{ll}
a_{11} & a_{12} \\
a_{21} & a_{22}
\end{array}\right]\left[\begin{array}{l}
Y_{t-1} \\
X_{t-1}
\end{array}\right]+\left[\begin{array}{l}
e_{y t} \\
e_{x t}
\end{array}\right]
$$

The error term in the standard VAR model can be expressed as linear combination of independently distributed shocks to $Y_{t}$ and $X_{t}$

$$
\left[\begin{array}{l}
e_{y t} \\
e_{x t}
\end{array}\right]=\frac{1}{1-b_{12} b_{21}}\left[\begin{array}{cc}
1 & -b_{12} \\
-b_{21} & 1
\end{array}\right]\left[\begin{array}{l}
\epsilon_{y t} \\
\epsilon_{x t}
\end{array}\right]
$$

If standard VAR model in 4.24 is iterated backward, and substitute 4.25 into the model, the model can be written in terms of a vector moving average,so $Y_{t}$ and $X_{t}$ can be expressed in terms of current and past values of the shocks to $\epsilon_{y t}$ and $\epsilon_{x t}$ 


$$
\left[\begin{array}{l}
Y_{t} \\
X_{t}
\end{array}\right]=\sum_{i=0}^{\infty}\left[\begin{array}{ll}
a_{11} & a_{12} \\
a_{21} & a_{22}
\end{array}\right]^{i}\left[\begin{array}{l}
a_{10} \\
a_{20}
\end{array}\right]+\frac{1}{1-b_{12} b_{21}} \sum_{i=0}^{\infty}\left[\begin{array}{ll}
a_{11} & a_{12} \\
a_{21} & a_{22}
\end{array}\right]^{i}\left[\begin{array}{cc}
1 & -b_{12} \\
-b_{21} & 1
\end{array}\right]\left[\begin{array}{l}
\epsilon_{y t-1} \\
\epsilon_{x t-1}
\end{array}\right]
$$

The second term on the RHS of 4.26 can be written as

$$
\frac{1}{1-b_{12} b_{21}} \sum_{i=0}^{\infty}\left[\begin{array}{ll}
a_{11} & a_{12} \\
a_{21} & a_{22}
\end{array}\right]^{i}\left[\begin{array}{cc}
1 & -b_{12} \\
-b_{21} & 1
\end{array}\right]\left[\begin{array}{l}
\epsilon_{y t-1} \\
\epsilon_{x t-1}
\end{array}\right]=\sum_{i=0}^{\infty}\left[\begin{array}{ll}
\emptyset_{11}(i) & \emptyset_{12}(i) \\
\emptyset_{21}(i) & \emptyset_{22}(i)
\end{array}\right]\left[\begin{array}{l}
\epsilon_{y t-1} \\
\epsilon_{x t-1}
\end{array}\right]
$$

Equation 4.27 states that the effects of shocks $\epsilon_{y t-1}$ and $\epsilon_{x t-1}$ on $Y_{t}$ are determined by the impacts multiplier $\emptyset_{11}(i)$ and $\emptyset_{12}(i)$, respectively. Similarly, effects of shocks $\epsilon_{y t-1}$ and $\epsilon_{x t-1}$ on $X_{t}$ are determined by $\emptyset_{21}(i)$ and $\emptyset_{22}(i)$, respectively.This approach to tracing out the time path by which $Y_{t}$ and $X_{t}$ respond to shocks $\epsilon_{y t}$ and $\epsilon_{x t}$ generates what is known as impulse response function.

However, there is a common identification problem in decomposing the residuals into shocks. This problem arises because there are 10 coefficients which need to be recovered in the structural model in 4.21 , but there are only nine coefficients which can be estimated from the standard VAR model (4.24) including $\operatorname{var}\left(e_{y t}\right), \operatorname{var}\left(e_{x t}\right)$ and $\operatorname{cov}\left(e_{y t} e_{x t}\right)$ using OLS.

Therefore, it is impossible to identify the structural model (4.21) unless restrictions are imposed on $b_{12}$ and $b_{21}$ in matrix $\mathbf{B}$.

To address this identification problem, we adopt a cholesky decomposition approach, which is conventionally used to orthogonalize the shocks in VAR analyses.

First, it is assumed that $b_{21}=0$ in equation (4.22). According to structural model (4.21), this implies that $Y_{t}$ i.e fiscal deficits has no contemporaneous effects on growth of monetary base $X_{t}$, only the previous value of the fiscal deficits can affect the growth of monetary base i.e $X_{t}$.

Equation 4.25 becomes

$$
\begin{array}{r}
e_{y t}=\epsilon_{y t}+b_{12} \epsilon_{x t} \\
e_{x t}=\epsilon_{x t}
\end{array}
$$

Responses may change dramatically if the ordering of the variables changes, the second ordering is specified by imposing restriction $b_{12}=0$. This assumption corresponds to the situation that $X_{t}$ i.e., growth of monetary base is contemporaneously affected by fiscal deficits $Y_{t}$ and only the shocks to $\epsilon_{y t}$ affects the contemporaneous values fiscal deficits i.e $Y_{t}$ in the VAR system. Then, equation 4.25 becomes

$$
\begin{gathered}
e_{y t}=\epsilon_{y t} \ldots \ldots \\
e_{x t}=b_{21} \epsilon_{y t}+\epsilon_{x t}
\end{gathered}
$$

Of significance to the discussion on fiscal dominance hypothesis is the testing of unidirectional causality, running from fiscal deficits to growth of monetary base and not vice versa (Gaiotti and Rossi, 2004). By implication, under the regime of fiscal dominance, the theoretical nexus is between the fiscal deficits and growth of monetary base.

Fiscal deficit is measured by excess of government expenditure over the generated revenue and is denoted in the estimation process as EGR. While growth of monetary base is measured by annual growth rate of high powered money and is denoted in the estimation process as CC. Time series data from 1986 to 2013 were sourced from Central Bank Statistical Bulletin, 2013.

\section{Empirical Results}

\section{Impulse response}

The SVAR impulse response functions of the impact of fiscal deficits shock and monetary base shock on fiscal deficits and monetary base, are plotted in fig 1. The lag length of the VAR model is selected using the Schwarz Information Criterion (also known as Bayesian Information Criterion because of its relative advantages over the others. It is relatively more consistent and it can also be used to compare models based on different probability distributions even as the Bayesian analytical paradigm incorporates estimation uncertainty and parameter uncertainty. Besides, the SC is relatively more conservative in terms of lag selection than the other information criteria. Also, diagnostic tests conducted showed that the estimated model is stable and there is no serial 
correlation among successive error terms in the VAR model.

From impulse response functions, a positive shock to fiscal deficit of government does not generate any response from growth of monetary base. However, in the second year, it yields a marginal negative impact on the growth of monetary base in the economy. From the third period, its impacts on growth of monetary base systematically approaches zero. The overall picture that emerges from the response of growth of monetary base to shock in fiscal deficits of government is that a shock to fiscal deficits of government does not stimulate response from the growth of monetary base in Nigeria. This implies the absence of fiscal dominance in Nigeria within the study period. In other words, fiscal dominance hypothesis could not be established in Nigeria.

The estimated results of causality tests are presented in table1. Empirical evidence from table 1 shows that there exists no causality running from fiscal deficits to growth of monetary base in Nigeria. The probability value in table 1, showing that causal relationship from fiscal deficits to growth of monetary base is not significant.The hypothesis of fiscal dominance requires existence of causal link from deficits (contemporaneous or previous) to money creation or growth of monetary base (Sabate et al. 2005). The result of causality test further affirms the absence of fiscal dominance hypothesis in the Nigeria economy.

Response to Cholesky One S.D. Innovations \pm 2 S.E.

Response of $D(C C)$ to $D(C C)$

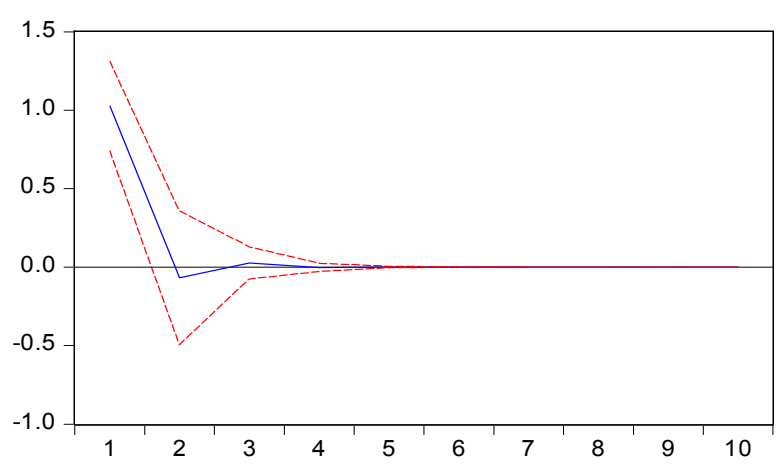

Response of $D(E G R)$ to $D(C C)$

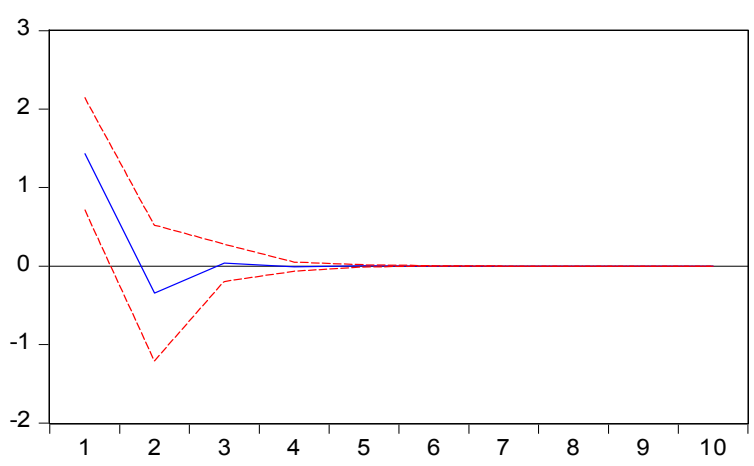

Response of $D(C C)$ to $D(E G R)$

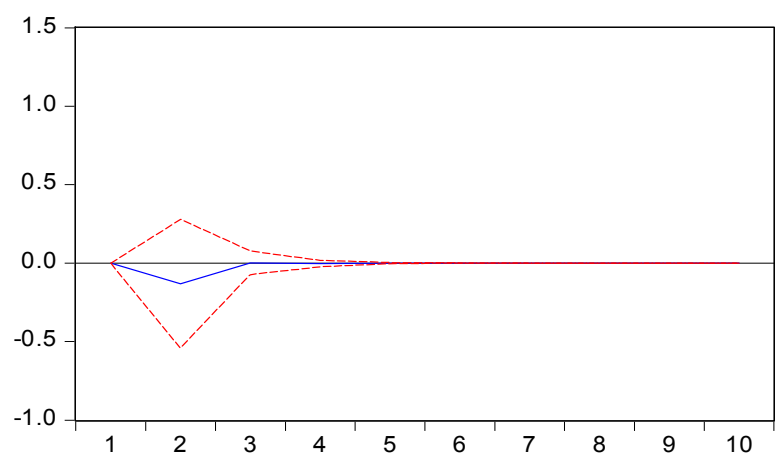

Response of $D$ (EGR) to $D(E G R)$

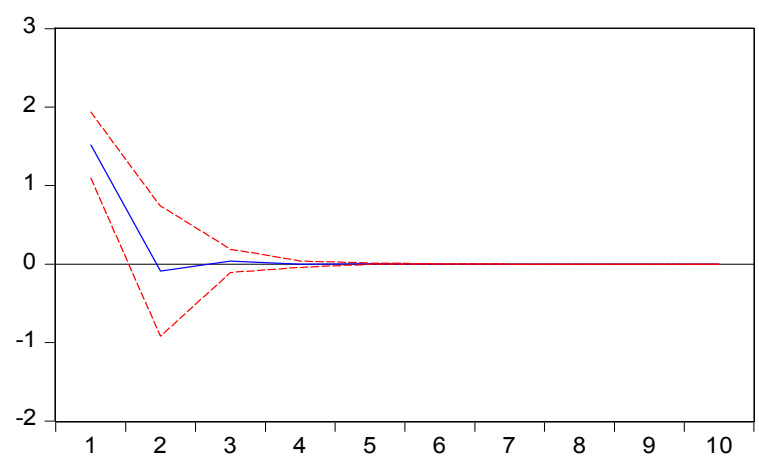

Figure 1

Table 1.VAR granger causality test results

\begin{tabular}{lll}
\hline DIRECTION OF CAUSALITY & F-Statistic & p-Value \\
\hline EGR $\rightarrow$ CC & 0.00637576 & 0.93701995 \\
$\mathrm{CC} \rightarrow$ EGR & 5.39119851 & 0.62904645 \\
\hline
\end{tabular}

The empirical evidence from this study shows the absence of fiscal dominance in Nigeria within the study period. In other words, fiscal dominance hypothesis could not be established in Nigeria. Looking at the growth of monetary base in Nigeria, the finding of the absence of fiscal dominance is not that surprising. This is because successive monetary policy in Nigeria has favoured more of tight monetary policy or credit ceiling than expansionary monetary policy. This has inhibited the growth of monetary base in Nigeria in response to 
successive fiscal deficits accumulation.

The current level of debt accumulation in Nigeria also implies that the large proportion of the fiscal deficits is financed by means of borrowing rather than creation of monetary base in the economy. For instance, the stock of debt in the economy as at 2015 stands at about \$US 60 billion (Debt Management Office, 2015). The absence of fiscal dominance in Nigeria could also be attributed to current inflationary targeting pursuit adopted by the monetary authority. Inflationary targeting regime stresses a high degree of transparency, supported by regular public statements that interpret inflation outcomes and explain monetary policy actions in terms of inflation objective. This would prevent monetary authority from unnecessary accommodation of fiscal policy since it is counter-productive to inflationary targeting policy.

\section{Concluding Remarks}

This study attempted to estabilish the presence or otherwise of fiscal dominance in Nigeria . The evidence provided in this study, based on the empirical findings showed that fiscal dominance could not be estabilished in Nigeria.The study therefore recommends that the government should further strengthen its fiscal consolidaton and creation of insttutional fiscal rules, while the CBN should also strengthen its analytical capacity to improve its monetary base forecasting level.

\section{References}

Aiyagari, R., \& Gertler, M. (1985). The backing of government bonds and monetarism. Journal of Monetary Economics, 16, 19-44. http://dx.doi.org/10.1016/0304-3932(85)90004-2

Ayodele, A., \& Falokun, G. (2003). The Nigerian Economy: Structure and Pattern.Lagos: Printoteque, p.20.

Bakare, A. O., Adesanya, O. A., \& Bolarinwa, S. A. (2014). Empirical Investigation between Budget Deficits, Inflation and Money Supply in Nigeria. European Journal of Business and Social Sciences, 2, 120-134.

Barro, R. J. (1987). Government Spending, Interest Rates, Prices, and Budget Deficits in the United Kingdom $\begin{array}{lllll}\text { 1701-1918. Journal of Monetary 221-247. } & \text { Economics, }\end{array}$ http://dx.doi.org/10.1016/0304-3932(87)90015-8

Bohn, H. (1998). The behaviour of U.S public debt and deficits. Quarterly Journal of Economics, 113, 949-964. http://dx.doi.org/10.1162/003355398555793

Canzoneri, M. B., Cumby, R. E., \& Diba, B. T. (2001), Is the price level determined by the needs of fiscal solvency? American Economic Review, 91(5), 1221-38. http://dx.doi.org/10.1257/aer.91.5.1221

De Resende, C. (2007). Cross-country estimates of the degree of fiscal dominance and central bank independence. Working Papers Bank of Canada: 07-36.

Ebiringa, T. O. (1998). The Macroeconomic Impact of Public Sector Deficits: An Empirical Study of Nigeria (1988-1997). Unpublished M.Sc. Research Work, Owerri, FUTO.

Favero, C. A. (2002). How do European monetary and fiscal authorities behave? Working papers 214, IGIER(Innocenzo Gasparini Institute for Economis Research), Bocconi University.

Favero, C., \& Spinelli, F. (1999). Testing Hypotheses on the Monetary History of Italy: 1875-1995. Economic Notes, 28, 43-71. http://dx.doi.org/10.1111/1468-0300.00004

Fratianni, M., \& Spinelli, F. (2001). Fiscal dominance and money growth in Italy: the long record. Explorations in Economic History, 38, 252-272. http://dx.doi.org/10.1006/exeh.2000.0753

Fry, M. J. (1998). Assessing central bank independence in developing countries: Do actions speak louder than words? Oxford Economic Papers, 50, 512-529. http://dx.doi.org/10.1093/oxfordjournals.oep.a028659

Gaiotti, E., \& Rossi, S. (2004). Theoretical and Institutional Evolution in Economic Policy: The Case of Monetary Regime Change in the Early 1980s. Storia del Pensiero Economico, 2, $20-27$.

Gallo, G. M., \& Otranto, E. (1998). Inflation in Italia (1863-1994): Nonlinearita è cambiamentidi regime. Universita diFirenze, Dipartimento di Statistical.

Joines, D. H. (1985). Deficits and money growth in the United States 1872-1983. Journal of Monetary Economics, 16, 329-351. http://dx.doi.org/10.1016/0304-3932(85)90040-6

Keen, B., \& Wang, Y. (2013). What is a realistic value for price adjustment costs in new keynesian models? Applied Economics Letters, 14, 789-793. http://dx.doi.org/10.1080/13504850600592739

Leeper, E. (1991). Equilibrium under 'active' and 'passive' monetary and fiscal policies. Journal of Monetary 
Economics, 27, 129-147. http://dx.doi.org/10.1016/0304-3932(91)90007-B

Makochekanwa, A. (2011). Impact of budget deficit on inflation in Zimbabwe. Journal of Economic Research, $1,49-59$.

Melitz, J. (1997). Some cross-country evidence about debt, deficits and the behavior of monetary and fiscal authorities. CEPR Discussion Papers 1653.

National Bureau of Statistics, Annual Reports and Statement of Accounts, NBS: Abuja (various issues).

Nawaz, M., Iqbal, M. M., Ali, A., \& Zaman, K. (2012). Fiscal theory of price level: A panel data analysis for selected SAARC countries. Romania Journal of Economic Forecast, 3, 152-170.

Ogunmuyiwa, M. S. (2008). Fiscal Deficit-Inflation-Nexus in Nigeria. Indian Journal of Economics, 3, 580-558.

Okonjo-Iweala, N. (2011). Securing a Diversified Economic Future for Nigeria. In Half a Century of Progress and Challenges: Ikokwu, C. C.True Expression.

Oladipo, S. O., \& Akinbobola, T. O. (2011). Budget Deficit and Inflation in Nigeria: A Causal Relationship. Journal of Emerging Trends and Economic Management Science, 2, 1-8.

Onwioduokit, E. A. (1999). Fiscal deficits and inflation dynamics in Nigeria: An empirical investigation of causal relationship. Central Bank Nigeria Economic and Financial Review, 37, 1-16.

Sabatè, M., Gadea, M. D., \& Escario, R. (2004). Does fiscal policy influence monetary policy? The case of Spain, 1874-1935. Explorations in Economic History, 43, 309-331. http://dx.doi.org/10.1016/j.eeh.2005.03.003

Sargent, T. J., \& Wallace, N. (1981). Some unpleasant monetarist arithmetic. Federal Reserve Bank of Minneapolis Quarterly Review, (Fall), 1-17.

Xiong, W. (2012). Measuring the monetary policy stance of People Bank of China: An ordered Probit analysis. China Economic Review. http://dx.doi.org/10.1016/j.chieco.2011.04.002

Zeileis,A. (2000). p values and alternative boundaries for CUSUM tests. Adaptive Information Systems and Modeling in Economics and Management Science Working Paper 78.

\section{Copyrights}

Copyright for this articleis retained by the author(s), with first publication rights granted to the journal.

This is an open-access article distributed under the terms and conditions of the CreativeCommons Attribution license (http://creativecommons.org/licenses/by/3.0/). 